\title{
IRRIGATION MODERNIZATION IN SPAIN: EFFECTS ON WATER QUANTITY AND QUALITY. A CONCEPTUAL APPROACH
}

\author{
Lecina, S. ${ }^{1}$, Isidoro, D. ${ }^{2}$, Playán, E. ${ }^{3}$, Aragüés, R. ${ }^{2}$
}

\begin{abstract}
This article analyses the effects of irrigation modernization processes on water quantity and quality, taking the Ebro River Basin (NE Spain) as a case study. The objective is to contribute to the needed in-depth analysis and discussion regarding the optimization of water use in agriculture. A conceptual approach based on water accounting concepts has been applied. Results show that irrigation modernization linked to an increase in land productivity involves additional water depletion if the location of the irrigated areas and the quality of the irrigation return flows allow their reuse. Also, modernization reduces the volume of return flows and pollutant loads and increases the quality of the receiving water bodies. The modernization of water management will be required to maximize economic, social and environmental returns from the investment in new irrigation infrastructures.
\end{abstract}

\section{INTRODUCTION}

\subsection{Water scarcity management in Spain}

Spain presents a Mediterranean climate over most of its territory. Relevant infrastructures have been built along its history for storing and delivering water. In

\footnotetext{
${ }^{1}$ Ager ingenieros, ingeniería rural y civil S.L. c/Mayor 53, 2 50001 Zaragoza, Spain.

2 Soil and Irrigation Department (associated with CSIC). Agrifood Research and Technology Centre of Aragon (CITA), Aragon Government. Avenida de Montañana 930, 50059 Zaragoza, Spain.

${ }^{3}$ Dept. Soil and Water, Aula Dei Experimental Station, CSIC. P.O. Box 13034, 50080 Zaragoza, Spain.

Present address of S. Lecina $(\bowtie)$ : Soil and Irrigation Department (associated with CSIC). Agrifood Research and Technology Centre of Aragon (CITA), Aragon Government. Avenida de Montañana 930, 50059 Zaragoza, Spain. E-mail: slecina@aragon.es Phone: +34 976713834
} 
addition, a world-pioneer legal frame was developed for regulating water use. The concept of unity of river basins for water resources management was introduced in the early $20^{\text {th }}$ century. Water User Associations were already introduced in the first Water Law that was drawn up in the $19^{\text {th }}$ century.

Spain's economic growth along the last decades has substantially increased water demand. However, water availability has hardly increased because of the lack of significant increments in water storage capacity. These facts have strengthened competition for water resources, and cyclical droughts have brought social conflicts between uses, users and regions within Spain (MARM, 2006).

The Spanish Government has introduced reforms to manage water demand. Public water rights banks, environmental taxes, or subsidies for irrigation modernization are just some examples. In addition, new water plans are being implemented through a participative and integrated process following the guidelines of the European Water Framework Directive.

One of the most ambitious plans is irrigation modernization. Spain has around 3.5 M ha of irrigated land. Although this surface only represents $13 \%$ of total agricultural land, it generates about 50 \% of the agricultural Gross Domestic Product (Forteza del Rey, 2002). Before the onset of these plans, surface irrigation amounted to $59 \%$ of the irrigated area, and $71 \%$ of the area had infrastructures more than 25 years old (MARM, 2002). About $72 \%$ of the irrigated area is located in land-locked provinces (INE, 1999). Surface irrigation is predominant on these provinces, where field crops occupy $74 \%$ of the surface irrigated area (MARM, 2007).

The two National Irrigation Modernization Plans (Plan Nacional de Regadíos and Plan de Choque de Modernización de Regadios) were designed with two main objectives: 1) to increase the competitiveness of the irrigation sector in order to face the progressive liberalization of agricultural markets and the reduction of subsidies, and 2) to save $3,000 \mathrm{Mm}^{3}$ water per year to alleviate the consequences of cyclical droughts in other sectors. This water saving represents $15 \%$ of the yearly average national agricultural water use. These plans aim to invest 7,400 M€ along this decade to improve the irrigation infrastructures of nearly $2 \mathrm{M}$ ha (MARM, 2002; MARM, 2006). 


\subsection{Analysis of agricultural water uses in Spain: irrigation efficiencies}

The concept of efficiency has been widely used to evaluate agricultural water use in Spain. Efficiencies have been traditionally applied for designing irrigation systems and scheduling irrigation or for computing maximum allowable withdrawals for irrigation. The water saving prospect of $3,000 \mathrm{Mm}^{3}$ is based on the reduction of water use due to the expected improvement of on-farm irrigation efficiency.

The efficiency approach divides the volume used to produce a product or service in two fractions. One is the water beneficially used for obtaining the product or service. The other is the water lost in the process. The relationships between each one of these partial volumes and the total volume determine the respective percentages of efficiency and water losses (Burt et al., 1997).

This methodology to evaluate water use is straightforward and intuitive. However, the efficiency approach does not take into account issues such as water reuse, the distinction between total water use and water consumption, and the influence of location of use within the basin and water quality. Irrigated agriculture is a non-point source of pollutants that causes quality degradation in the water bodies receiving the irrigation return flows, decreasing its capability to reuse (Ongley, 1996).

These issues are particularly important for water management in a context of water scarcity in a basin. For these reasons, several authors have pointed out that the efficiency concept is not appropriate for assessing the hydrological impact of irrigation in a basin (Willardson et al, 1994; Seckler, 1996; Perry, 1999; Jensen, 2007; Perry, 2007).

\subsection{The water accounting approach}

Although several authors have included the abovementioned hydrological issues in a new formulation of the efficiency called "effective efficiency" (Keller et al., 1996; Seckler et al., 2003; Mateos, 2008), water accounting has been proposed as an alternative for hydrological purposes (Molden and Sakthivadivel, 1999; Clemmens et al., 2008; Perry et al., 2009). This methodology applies the law of conservation of mass through water balances.

Balances identify the destination of the water used and distinguish four sinks of irrigation water (Molden and Sakthivadivel, 1999; Perry et al., 2009): 1) Beneficial 
evapotranspiration; 2) Non-beneficial evapotranspiration; 3) Non-recoverable runoff/percolation; and 4) Recoverable runoff/percolation. The two first elements in relation to the total water use constitute the consumed fraction. Evapotranspiration and non-recoverable runoff/percolation make up the fraction of the total water use that is depleted in a basin.

\subsection{Objectives}

The objective of this work is to contribute to the needed in-depth analysis and discussion regarding the optimization of water use in agriculture. The results of this analysis are expected to provide insight on the consequences of irrigation modernization on water availability and quality.

The consequences of this modernization process on water quantity and quality are analyzed through a conceptual approach applied to the Ebro River Basin (ERB) as a case study. The application of basic hydrologic concepts to irrigation modernization constitutes a secondary objective of this work. The study is based on the authors' 30-year research experience in the Ebro River Basin as well as in a number of experiences around the world.

A clear understanding of the farmers' motivation for irrigation modernization is needed to anticipate the consequences of this process. The two following sections describe the irrigated areas of the ERB and explain their socio-economic context. Subsequent sections analyse the impacts of irrigation modernization on water quantity and quality in the basin and policy implications. 


\section{THE IRRIGATED AREAS OF THE EBRO RIVER BASIN}

The Ebro River Basin is one of the most important watersheds of the Iberian Peninsula, covering $15 \%\left(85.566 \mathrm{~km}^{2}\right)$ of its territory. Located in northeast Spain (Figure 1), its irrigated area is about 800,000 ha ( $24 \%$ of total Spanish irrigated land).

About $73 \%$ of the irrigated area, including the largest irrigation projects, is located in the central ERB. The climate in this part of the basin is semi-arid, particularly in the area surrounding the Ebro River. Mean annual temperature is $14{ }^{\circ} \mathrm{C}$, and an annual precipitation oscillates between $300 \mathrm{~mm}$ and $450 \mathrm{~mm}$. A dry period typically extends from July to September. The annual reference evapotranspiration (Hargreaves and Samani, 1985), varies from $949 \mathrm{~mm}$ to $1,157 \mathrm{~mm}$. The average windspeed (at $2.0 \mathrm{~m}$ height) ranges between $0.6 \mathrm{~m} \mathrm{~s}^{-1}$ and $2.6 \mathrm{~m} \mathrm{~s}^{-1}$.

Soils of the river terraces, where the oldest irrigated areas of the ERB are located, generally cover limestone gravel deposits, are well drained and present favourable characteristics for surface irrigation. The irrigation projects developed in the $20^{\text {th }}$ century extended the irrigated land outside these areas, covering platforms, slopes and alluvial terraces. Platform soils sit on tertiary materials covered with gravel. These soils are highly productive because of their low slope and adequate drainage but often present low surface irrigation efficiency due to their low available water holding capacity (AWHC) and high infiltration (Playán et al., 2000). Soils in slopes and alluvial terraces are characterized by high AWHC but poor drainage. Some of them are naturally salt-affected and others are salt-affected because of levelling, seepage, or particularly low internal drainage. Spots of saline-sodic soils occur in these soils, although sodicity is often associated to irrigation in areas lacking gypsum (Herrero and Snyder, 1997).

Irrigation technology is very variable due to the long history of irrigation development in the region. Small irrigated areas were established close to the rivers during the last 2,000 years. The first big canals were built parallel to the Ebro River and the Segre River in the $18^{\text {th }}$ and $19^{\text {th }}$ centuries (about 87,100 ha). The great expansion of the irrigated area took place in the mid-20 th century, when massive surface irrigated projects based on large canals and reservoirs built mainly on Pyrenean rivers were promoted by the Government (about 327.300 ha). Sprinkler and drip irrigated areas 
were developed in the last 40 years. Before the establishment of the irrigation modernization plans in 2002, around $70 \%$ of the irrigated area was irrigated by traditional surface irrigation systems, $19 \%$ by sprinkler systems and $11 \%$ by drip irrigation (CHE, 2005).

Figure 2 shows the cropping pattern in the irrigated area of the ERB as an average of the 1996 to 2002 seasons. This cropping pattern was obtained from the Government databases used to pay the European Common Agricultural Policy (CAP) subsidies. This period is prior to the beginning of the irrigation modernization process. Field crops occupied $58 \%$ of the total area. Fruit trees and vegetables were present in $19 \%$ of the area, and olive trees and vineyards were cultivated in $4 \%$. Approximately $17 \%$ of the irrigated area was not cropped, mainly due to the archaic structures of the oldest irrigated areas, the low water conveyance capacity of the networks of ditches built in the mid-20th century, the land set aside CAP subsides and the presence of salt-affected soils (Nogués et al., 2000). 


\section{RURAL SOCIETY AND IRRIGATION MODERNIZATION IN THE EBRO RIVER BASIN}

The agrifood system based mainly on the irrigated areas generates about $12 \%$ of the Gross Added Value and $14 \%$ of the employment in the basin. Agriculture and subsidiary sectors are virtually the only economic activity in many rural regions (CHE, 2005). CAP has supported agricultural production and its commercialization during the last decades. Agricultural subsidies have been a key factor in farms' profits in the ERB, particularly in areas specialised in field crop production. The ongoing liberalization of agricultural trade is bringing sharp decreases in subsidies applied to the crop area, among other measures. This process has resulted in a reduction of subsidies to field crops of about $75 \%$ in the last five years.

The liberalization of agricultural trade and the decreased influence of CAP in agricultural markets are also bringing an increase of the variability of crop prices. These prices are now much more influenced by multiple and changing factors in time and space, such as world weather, economic and population growth, energy prices, or investment in rural development. These factors have increased the average annual variability of the grain prices at the local agricultural stock exchange Lonja del Ebro from $5 \%$ to $20 \%$ in the last five years. This volatility is expected to continue through the upcoming years, increasing the uncertainty of the farms' net profits (OECD-FAO, 2009).

Spanish economic growth during the last decades has supposed a large reduction in availability and quality of agricultural labour. Young people in rural areas prefer urban jobs because these have higher income and higher technology level than agricultural jobs. This trend is stressed by the low population density characterizing the basin. The average population density is 33 inhabitants per square kilometre, but it is less than 5 in $40 \%$ of the territory (CHE, 2005).

About $92 \%$ of agricultural water comes from surface water supplies, mainly from the Pyrenean rivers, and only $8 \%$ from groundwater. Average agricultural water use is about $8,000 \mathrm{~m}^{3} \mathrm{ha}^{-1}$ (accounted from the water source) (MARM, 2000). The change of land uses in headwater regions of the basin, from crops and pastures to scrubs and forests due to the depopulation of this territory, have led to a marked reduction in 
water availability. In the case of Central Spanish Pyrenees Mountains these changes have resulted in a stream flows reductions of about $30 \%$ since the mid-20th century (Beguería et al., 2003). Moreover, changes in precipitation, temperature, and snow accumulation are further contributing to these reductions. If current trends in landcover and climatic conditions continue along the present century, the balance between available resources and water demand could be seriously threatened (López-Moreno et al., 2008).

Irrigated agriculture may contribute to the degradation of water quality because of the salt and agrochemical loadings in irrigation return flows. Although water quality is generally adequate for irrigation in the rivers of the ERB in regard to salinity, nitrate and phosphorus (Isidoro and Aragüés, 2007), local problems have been described in reservoirs, lakes and aquifers (CHE, 2005). Nine vulnerable zones to nitrate pollution from agricultural sources have been declared. Environmental restrictions on agricultural activities are applied in these zones. These restrictions will undoubtedly be stressed in coming years in the basin since "good environmental status" must be achieved in all water bodies of the basin before 2015 according to the European Water Framework Directive.

The productive structure and management of the farms must be competitive, flexible and environmentally friendly to cope with this socio-economic context (Playán and Mateos, 2006). Increasing productivity is essential to achieve farm sustainability. Investments in irrigation should consider these requirements, among others (Turral et al., 2009). Irrigation modernization, including both structural and managerial aspects, stands as an adequate alternative to the central ERB (Albiac et al., 2007; Playán et al., 2007).

Therefore, these facts stand as the main reason why farmers invest in modernizing their irrigation structures. Pressurized irrigation systems provide higher productivities than traditional surface irrigation systems in the ERB. More intensive cropping patterns and higher yields explain this difference.

Before the beginning of the irrigation modernization process in the ERB, $42 \%$ of the surface irrigated area was occupied by low value crops (winter field crops, like barley and wheat) and fallow plots, in contrast to only $20 \%$ in the pressurized irrigated area 
(Figure 2). Horticultural crops, orchards, vineyards and summer field crops (mostly corn and alfalfa) were present in $77 \%$ of the sprinkler and drip irrigated land.

Figure 3 illustrates the difference in gross land productivity between irrigation systems by crop groups in the ERB. Gross land productivity was computed as the ratio between the gross value of production and the cropped area (Molden et al., 1998). Average yields and prices were obtained by survey among irrigation districts managers and from Government statistics during 2003 and 2004 in the central ERB. These data were extrapolated to the whole basin for homogeneity in comparison (MARM, 2004 and 2005). Gross land productivities are about $37 \%$ higher in sprinkler and drip irrigated crops due to higher yields. Only vineyards present similar productivities between irrigation systems due to severe yield limitations imposed to achieve quality certified wines.

In addition to these factors, irrigation automation reduces labour requirements. In old surface irrigation systems in the ERB, one person can irrigate about 50 ha, but more than 200 ha can be irrigated with the new pressurized systems. Irrigation modernization leads to increased labour productivity, reduced labour tensions, and improved working conditions for farmers.

On the average, farmers' cost for switching from surface to pressurized irrigation systems (sprinkler or drip) is about 9,000 € ha-1, a value similar to the market value of the land. Additionally, energy-related water costs are higher in pressurized irrigation.

Although properly designed and managed surface irrigation systems can perform just as well as pressurized systems (Clemmens and Dedrick, 1994), farmers choose to change the irrigation system in most cases. Irregular topography, small plot size, high labour requirements, and low flexibility are some factors that reduce the productivity of surface irrigation systems in the ERB.

About 175,000 ha are planned to change their surface irrigation systems during the current decade in the ERB (MARM, 2002; MARM, 2006). This area is mainly located in the large surface irrigation projects developed in the mid-20 th $c e n t u r y$. Older irrigated areas hardly change their surface irrigation systems because they present very small land tenure since they were established before the mechanization of the agriculture, among other reasons. Nevertheless, some of them are improving their networks of 
irrigation ditches. The Government partially supports these efforts in irrigation modernization with subsidies and/or financial aids.

Therefore, the irrigation modernization process in the ERB will involve an increase in crop production and a change in water use practices. These changes will have strong hydrological implications in the basin. 


\section{CONSEQUENCES OF IRRIGATION MODERNIZATION ON WATER QUANTITY}

\subsection{Beneficial evapotranspiration}

Beneficial evapotranspiration is referred to crop evapotranspiration. Proper irrigation scheduling and water application are needed to satisfy crop water requirements.

The old surface irrigation conveyance networks in the ERB were designed at least 50 years ago for low-productivity agriculture based on winter cereals. The low conveyance capacity of the old networks of ditches, coupled to the large irrigation depth generally applied by surface irrigation, often do not allow for adequate irrigation scheduling. Old surface irrigation projects usually present excessively long irrigation intervals. Faci et al., (2000) and Lecina et al. (2005) described how farmers tend to apply large irrigation depths because of the uncertainty about when they will irrigate again in the surface irrigated areas of the central ERB. These large irrigation depths do not improve crop water supply and extend the irrigation interval. These authors reported that these intervals are about 10-14 days during the peak months, despite $24 \mathrm{~h}$ daily operation periods.

In soils with low available water holding capacity, crop water requirements are satisfied only partially due to these long irrigation intervals. If the water available for the crop is not enough to meet its maximum transpiration rate, yields fall below potential levels because of the linear relationship between crop biomass and transpiration (Steduto et al., 2007; Molden et al., 2009).

Isidoro et al. (2004), applying water balances in the surface irrigated area of the Violada Canal, reported that evapotranspiration is $16 \%$ lower than potential. Lecina and Playán (2006a, 2006b) obtained differences about 15 \% using combined irrigation-crop models in the Bardenas Canal, other surface irrigated area in the central ERB. These differences between real and potential evapotranspiration have been found in other surface irrigated areas in the world (Allen et al., 2005).

In contrast, Tedeschi et al. (2001) and Cavero et al. (2003) pointed out that evapotranspiration is close to potential in the modern sprinkler irrigated area of the Monegros II scheme, according to the water balances carried out in this area of the 
central ERB. New pressurized networks present higher capacity, reliability, and flexibility in water delivery than traditional irrigation ditches. Furthermore, properly designed and managed sprinkler and drip irrigation systems allow farmers to better adjust irrigation depth and frequency to meet the local soil, crop and meteorological features. Zapata et al. (2009) reported the capability of these pressurized networks and irrigation systems to achieve a high quality irrigation performance in the new irrigated areas of the central ERB. Therefore, crop water requirements are adequately satisfied and crop evapotranspiration is close to potential in these areas.

These characteristics of the new pressurized networks also allow farmers to grow more productive crops like horticultural, orchards or summer field crops than in traditional surface irrigated areas. These crops generally present higher water requirements (although there are exceptions like vineyards and olive trees). In some areas (where summer seasons are long enough), it is even possible to grow two or three crops per season.

These differences between irrigation systems in the ERB underline that better water supply means higher crop evapotranspiration and higher crop yields because of the abovementioned biological crop-water relations. Figure 4 shows average crop evapotranspiration per unit area and gross land productivity by irrigation system in the whole ERB. The cropping pattern presented in Figure 2, discriminated by region and irrigation system, and the gross land productivities showed in Figure 3 were used. In the figure, evapotranspiration corresponds to the $50 \%$ return probability obtained from Martínez-Cob (2004) for each crop and region in the ERB following the methodology proposed by Allen et al. (1998). An average $15 \%$ reduction was applied to the potential evapotranspiration in surface irrigated areas regarding the limitations of their irrigation structures. The evapotranspiration per unit area in sprinkler areas was $27 \%$ higher than in surface irrigated areas and land productivity 3.5 times higher. Approximately, one half of this difference in evapotranspiration is due to the different cropping patterns.

Water productivity, computed as the ratio between gross land productivity and beneficial evapotranspiration per unit area (Molden et al., 1998; Playán and Mateos, 2006), is $0.508 € \mathrm{~m}^{-3}$ in surface irrigated areas, and $1.415 € \mathrm{~m}^{-3}$ in pressurized areas. This 
difference implies a competitive advantage of pressurized systems in drought years, and a more profitable use of the water resources in the basin.

\subsection{Non-beneficial evapotranspiration}

Non-beneficial evapotranspiration includes evapotranspiration from non-productive plants (like weeds or phreatophytes) and direct evaporation from water bodies. This non-beneficial consumption is common in surface irrigation areas where ditches are present, due to leakages and open water surfaces. The volume of these water flows mainly depends on the maintenance of the structures.

Pressurized networks reduce the volume of water used by non-productive vegetation because they virtually eliminate leakages. Additionally, dikes, where this vegetation is present, are not required inside sprinkler and drip irrigated plots in contrast to borders and basins in surface irrigation. Pipelines also eliminate direct evaporation. However, pressurized irrigated areas usually present small reservoirs (typically less than $1 \mathrm{Mm}^{3}$ in capacity) to increase water storage within them. These reservoirs increase the water surface exposed to evaporation. Nevertheless, Krinner et al. (1994) reported that the relative volume of this non-beneficial water consumption is generally low in surface and pressurized large irrigation projects of the ERB and other Spanish basins.

In the specific case of sprinkler irrigated areas, wind drift and evaporation losses (WDEL) can also be considered as non-beneficial water consumption (Burt et al., 1997). Although a small part of these losses may contribute to reduce crop evapotranspiration due to a modification in plot microclimate (Martínez-Cob et al., 2008), WDEL may notably increase the non-beneficial component of the balance. Several authors have pointed out that WDEL can vary between 10 and $20 \%$ of the total water applied in the sprinkler irrigated areas of the central ERB (Dechmi et al., 2003; Playán et al., 2005). This magnitude depends on the design and management of the irrigation system, and on the weather conditions. The central ERB, particularly near the Ebro River, is characterized by strong winds, a key factor on WDEL. In the conditions of this area, Zapata et al. (2007) reported that decreasing WDEL below $10 \%$ is strongly limited by the cost of the required structures and the low value of field crops. 


\subsection{Runoff/Percolation}

Runoff/Percolation comes from irrigated plots and conveyance structures. Field evaluation campaigns carried out in surface irrigated areas of the Bardenas Canal obtained on-farm application efficiencies (Burt et al., 1997) about $40 \%$ in areas where soils are characterized by low AWHC and high infiltration rates (Lecina et al. 2005). Where soils present more favourable conditions to surface irrigation, application efficiencies were about 60 \% (Lecina et al., 2005). Similar values were obtained by Playán et al. (2000) and Lecina et al. (2000) in other surface irrigated areas of the ERB. Water balances carried out in the Violada Canal and the Bardenas Canal obtained return flows equivalent to approximately $50 \%$ of the water inflows (Isidoro et al., 2004; Causapé et al., 2004a,b).

In contrast, field evaluation campaigns performed in pressurized irrigated areas of the Cinca Canal and the Ebro River showed average on-farm efficiencies around $80 \%$ (Dechmi et al. 2003). Tedeschi et al. (2001) and Cavero et al. (2003) obtained return flows which represented between $5 \%$ and $11 \%$ of the inflows in water balances carried out in the sprinkler irrigated area of the Monegros II scheme.

The authors or these studies reported that virtually all runoff/percolation volumes return to the rivers. The quality of these returns allows other users to reuse them, as will be explained in the next section. Approximately $30 \%$ of these flows are reused within the same surface irrigation projects where they are generated (Causapé et al. 2006; Causapé, 2009). The remaining irrigation return flows can be reused downstream by other users along the basin. Only $6 \%$ of the irrigated area in the ERB is located at a distance lower than $100 \mathrm{~km}$ from the Mediterranean Sea, following the course of the Ebro River. Salt lakes or other sinks where water is non-recoverable inside the ERB are small and have little impact on irrigation return flows according to Castañeda and García-Vera (2008) and CHE (2005). These facts result in a low non-recoverable runoff/percolation.

\subsection{Water depletion}

The reusability of irrigation return flows, and the low volume of non-beneficial evapotranspiration, convert beneficial evapotranspiration into the main component of the depleted fraction, and leave a limited margin for real water savings in the ERB. The 
change of irrigation system and the intensification of crop production as a consequence of irrigation modernization will result in an increase in water depletion despite the improvement of on-farm efficiencies, particularly in the cases of switching from surface to sprinkler irrigation owing to WDEL. The overall effect on water demand will depend on whether the increase in evapotranspiration is higher or lower than the decrease in runoff/percolation.

Considering the cropping pattern by irrigation system prior to the modernization (Figure 2), the planned change of irrigation systems in 175,000 ha will involve an increase of about $141 \mathrm{Mm}^{3}$ (from $2,426 \mathrm{Mm}^{3}$ to $2,567 \mathrm{Mm}^{3}$ a year) in the beneficial evapotranspiration of the ERB (50\% return probability). WDEL should be added to this volume in the cases of switching from surface to sprinkler irrigation to estimate the total increase in water consumption. This increment implies an equivalent reduction of water availability in the basin.

There are many factors influencing the cropping pattern, and therefore the water consumption. Winter cereals and fallow plots will not be completely eliminated in modernized areas because rotation of field crops is needed for weed control, and saltaffected areas barely go through modernization. The international prices of agricultural commodities and energy will dynamically adjust the degree of crop intensification in a fully liberalized context (IBRD, 2009). Additionally, future water restrictions and growing market competition could force out of production marginal farms, i.e. non-modernized farms. Regulated deficit irrigation techniques (RDI) could be encouraged by the foreseen agricultural context. 


\section{CONSEQUENCES OF IRRIGATION MODERNIZATION ON WATER} QUALITY

Water pollution is a key factor in water availability. In land-locked irrigated areas "evapoconcentration" and "weathering" are two main water quality degradation processes induced by irrigation (Aragüés and Tanji, 2003). The impact of irrigation modernization in water quality will depend on the relative importance of these processes.

"Evapoconcentration" is a process in which a fraction of a water volume is evapotranspired and the remaining fraction gets more concentrated, as it holds the total pollutant (normally salt) load of the whole initial water volume. The salinity of the irrigation water is the most important variable from the point of view of this process. If the salinity is high, the higher consumed fraction in the modernized areas could increase soil solution salinity to levels harmful for crop production. In addition, this increase in soil solution salinity may lead to the precipitation of some low soluble Ca-minerals, therefore increasing soil solution sodicity and the corresponding negative effects on the structural stability of soils. This effect is also potentially negative for users who directly use the irrigation return flows.

The salinity of the irrigation water is generally low in the ERB (usually $<0.4 \mathrm{dS} \mathrm{m}^{-1}$ at $25^{\circ} \mathrm{C}$ ) (Isidoro and Aragüés, 2007). Hence, the impact of the "evapoconcentration" process following the irrigation modernization will also be low. This fact will allow optimum on-farm irrigation efficiencies because large leaching fractions will not be required for a proper control of the potential negative "on-site" effects (i.e., soil salinization and sodification).

"Weathering" is a process in which a mass of a solid is added to a given water volume. Switching from surface to pressurized irrigation contributes to reduce the "weathering" process because lower percolation volumes decrease mineral dissolution and, depending on the leaching fraction, may promote mineral precipitation. Moreover, fertigation applied with pressurized systems might improve fertilization scheduling and reduce fertilizer doses in relation to old surface irrigation systems, therefore decreasing the "input" effect. 
Table 1 shows the salt and nitrate concentrations and loads measured in the irrigation return flows (IRF) of six study areas located in the central ERB. The pressurized irrigated areas present lower return water volumes and lower salt and nitrate loads than the surface irrigated areas. Salts loads mainly depend on soil salinity and the salinity of underlying geological strata (the two sprinkler areas were high in geologic salts), whereas nitrate loads are much lower in high-efficiency sprinkler irrigated areas than in low-efficiency surface irrigated areas.

The intensification of crop patterns may increase the total amount of agrochemicals and, in particular, fertilizers applied in an irrigation area, therefore increasing the "input" effect. Hence, if fertilization management is not adequate, the mass of fertilizers exported in drainage water could increase. Recent experiences in sprinkler irrigated areas of the ERB show that, in general, this has not been the case (Cavero et al., 2003; Tedeschi et al., 2001). Similar consequences may occur in the case of other agrochemicals, although the most dangerous, slow-degrading herbicides and pesticides are being progressively banned by European Union regulations.

In the ERB, as in most arid and semiarid inland irrigated areas, the "weathering" process is more important than the "evapoconcentration" process because of the vast presence of minerals in the soil or subsoil (Herrero and Snyder, 1997). Since the volume of return flows will decrease, the salt load will be reduced by the modernization process, and the quality (i.e., dissolved solids concentration) of the receiving water bodies will be improved.

These changes in volume and pollutant loads of IRF will also lead to increases in the concentration of these pollutants in the return flows (Table 1). Therefore, after modernization the direct users of these return flows will have reduced water availability, both in terms of quantity and quality. If these return flows are the only water available for these users, other water sources should be allocated to them to compensate for decreased water availability. 


\section{POLICY IMPLICATIONS}

The findings obtained in this work point out that the irrigation modernization policy set up by the Government of Spain will effectively contribute to enhance the economic, social and environmental conditions of the agricultural sector. Competitiveness will improve due to an enhancement of the irrigation infrastructures. Farmers' working conditions will be greatly ameliorated and these jobs will be more attractive to young rural people. Socio-economic development will be underpinned in rural regions, contributing to maintain a territorial balance. Reductions in the export of pollutant loads from irrigated areas will entail a global improvement of water quality, thus contributing to achieve the environmental goals of the European Water Framework Directive.

However, irrigation modernization will not result in water savings at the basin scale. In cases such as the ERB, where most of the return flows can be reused, the increase in crop yields will lead to an increase in evapotranspiration and therefore in water depletion. This fact will stress competition for water resources where water is scarce. As a consequence, irrigation modernization will not prevent or solve water conflicts.

Irrigation modernization represents a step forward in the process of conversion from protected to competitive agriculture. In a context of growing demand of food for an increasing world population, open markets involve an intensification of resource use. If these resources (such as water or land) are limited, their productivity must be increased. Achieving high productivity requires technology, but also knowledge and skills. Therefore, the modernization of water management is required in addition to the modernization of irrigation structures.

Modernizing water management requires addressing the three levels of responsibility: farmers, Irrigation Districts and River Basin Authorities. Following modernization, farms will be equipped with new irrigation systems and electronic controllers capable of applying an advanced irrigation scheduling. Farmers must know manage these systems to obtain the maximum benefit from water, fertilizers and other inputs (Tedeschi et al., 2001; Cavero et al., 2003; Dechmi et al., 2003). This task will be increasingly complex in a context of high variable prices of crops, increased energy prices and water scarcity. 
This complexity will lead farmers to request more services from Irrigation Districts. The districts will have to optimize the performance of their new pressurized water conveyance networks to provide added-value services supporting farmers to achieve their goals. Collective remote control and monitoring systems are being installed in these networks as part of the modernization process. Simulation models and benchmarking techniques must be applied by specialised district personnel to obtain the best performance from these new and complex structures (Zapata et al., 2009).

River Basin Authorities should provide the adequate conditions to optimize socioeconomic returns from water use, to achieve the "good environmental status" of all water bodies and to prevent social conflicts. Development of the water accounting concepts will be required, particularly in basins or sub-basins affected by water scarcity. Increased efforts in water use data collection (identifying the destinations of the water used) will be required, so that accurate water balances can be developed on a routine basis.

Water management modernization will probably require a modification of the water legal frame. The core of this legislation was developed many years ago in different socio-economic circumstances, when scarcity was mainly due to the lack of technology and investments to develop water resources. In the current water law, the rights are based on water withdrawals. There is not a clear distinction between water use and water depletion, and the efficiency concept is applied to estimate irrigation water demand. Where water is scarce, computation of water withdrawal instead of water depletion could lead to misunderstandings, undermining the decision making process and the required transparency, key factors in an integrated water management system.

Moreover, from a water quality perspective policy and legislation will have to be modified or expanded to take into account water pollution problems originating from irrigated agriculture. Currently, the European Water Framework sets limits on pollutant concentrations in order to achieve a "good environmental status" of water bodies. However, total maximum daily loads that can be exported to each water body are not determined. This approach would contribute to promote improvements on water, fertilizer and agrochemical management.

Water management modernization will be much cheaper than infrastructure modernization. However, increased efforts in training and research will be required at 
all levels: farms, Irrigation Districts and River Basin Authorities. The government should promote this process because it will be essential to achieve the maximum economic, social and environmental returns from the ongoing public and private investments in irrigation modernization. 


\section{CONCLUSIONS}

The irrigation modernization process linked to an increase in land productivity implies an increase in beneficial evapotranspiration. If the location of the irrigated areas and the quality of the irrigation return flows allow their reuse, like in the Ebro River Basin, this increase in beneficial evapotranspiration results in a net increase in water depletion. In these cases, non-beneficial evapotranspiration and non-reusable runoff/percolation are low. Only sprinkler irrigated areas present sizeable nonbeneficial evapotranspiration due to WDEL, contributing to increase water depletion when modernization implies switching from surface to sprinkler irrigation. Therefore, water availability will be reduced, owing to the irrigation modernization and despite the increase in on-farm irrigation efficiency.

The magnitude of the increase in the beneficial evapotranspiration will depend on the previous conditions of the traditional surface irrigation systems. Additionally, crop and energy prices, water availability and competitiveness of farms will influence the future headway of water depletion.

Irrigation modernization will benefit the quality of the water bodies in semi-arid irrigated areas. Increasing the consumed fraction will reduce the volume of return flows and pollutant loads from irrigated areas because of the reductions in water percolation. However, following modernization, direct users of return flows will have access to less water with higher pollutant concentrations.

The importance of these effects on water quality heavily relies on the adequate management of water and fertilizers, as well as on salinity of soils, geological strata and irrigation water. New high-tech irrigation structures will ease this management.

Water accounting should be applied instead of the irrigation efficiency approach for a clear understanding of the impact of irrigation in the hydrology of a basin. Complete development of this methodology requires increased efforts in water use and water and soil quality monitoring. A water management modernization plan and changes in some aspects of the current water legislation will be required to achieve this goal. The conceptual application of water accounting in the Ebro River Basin has showed that if water savings are intended, efforts should focus on evapotranspiration management, rather than only on-farm irrigation efficiency. 


\section{ACKNOWLEDGEMENTS}

Thanks are due to Silvia Lozano and Idoia Ederra (Riegos de Navarra S.A.), Segundo Herráez and Eva Díaz de Arcaya (Diputación Foral de Álava), Antonio Enjuanes and Joan Anglés (Generalitat de Cataluña) and Miguel Ángel Monsalve (Ager ingenieros irc S.L.) for supplying and processing part of the data used in this study. Thanks are also due to the rest of researchers of our Departments for the review of a preliminary version of this study. 


\section{REFERENCES}

Albiac, J., Playan, E., \& Martínez, Y. (2007) Instruments for water quantity and quality management in the agriculture of Aragon, International Journal of Water Resources Development, 23(1), pp. 147-164.

Allen, R.G., Pereira, L.S., Raes, D. \& Smith, M. (1998). Crop evapotranspiration. Guidelines for computing crop water requirements, FAO Irrigation and Drainage Paper no. 56 (Rome, FAO).

Allen, R.G., Clemmens, A.J., Burt, C.M., Solomon, K. \& O’Halloran, T. (2005) Prediction accuracy for projectwide evapotranspiration using crop coefficients and reference evapotranspiration, J. Irrig. and Drain. Engrg., 131(1), pp. 24-36.

Aragüés, R. \& Tanji, K.K. (2003) Water Quality of Irrigation Return Flows, in: B.A. Stewart \& T.A. Howell (Ed.) Encyclopedia of Water Science (New York, Marcel Dekker Inc.).

Basso, L. (1994. Los retornos salinos del polígono de riego Bardenas I y su contribución a la salinización de los ríos Arba y Riguel, PhD Dissertation (Zaragoza, Universidad de Zaragoza).

Beguería, S., López-Moreno, J. I., Lorente, A., Seeger, M. \& García-Ruiz, J. M. (2003) Assessing the effect of climate oscillations and land-use changes on streamflow in the Central Spanish Pyrenees, Ambio, 32(4), pp. 283-286.

Burt, C.M., Clemmens, A.J., Strelkoff, T.S., Solomon, K.H., Bliesner, R.D., Hardy, L.A., Howell, T.A. \& Eisenhauer, D.E. (1997. Irrigation performance measures: Efficiency and uniformity, J. Irrig. and Drain. Engrg., 123(6), pp. 423-442.

Castañeda, C. \& García-Vera, M. A. (2008) Water balance in the playa-lakes of an arid environment, Monegros, NE Spain, Hydrogeology Journal, 16(1), pp-87-102.

Causapé, J., Quílez, D. \& Aragüés, R. (2004a) Assessment of irrigation and environmental quality at the hydrological basin level - I. Irrigation quality, Agric. Wat. Manage., 70(3), pp. 195-209. 
Causapé, J., Quílez, D. \& Aragüés, R. (2004b). Assessment of irrigation and environmental quality at the hydrological basin level - II. Salt and nitrate loads in irrigation return flows, Agric. Wat. Manage., 70(3), pp. 211-228.

Causapé, J., Quílez, D. \& Aragüés, R. (2006) Irrigation efficiency and quality of irrigation return flows in the Ebro River Basin: An overview, Environmental Monitoring and Assessment, 117(1-3), pp. 451-461.

Causapé, J. (2009) Agro-environmental evaluation of irrigation land I. Water use in Bardenas irrigation district (Spain), Agric. Wat. Manage., 96(2), pp. 179-187.

Cavero, J., Beltrán, A. \& Aragües, R. (2003) Nitrate exported in the drainage water of two sprinkler irrigated watersheds, J. Environ. Qual., 32, pp. 916-926.

CHE (2005) Caracterización de la demarcación y registro de zonas protegidas, Implantación de la Directiva Marco del Agua, Demarcación Hidrográfica del Ebro (Zaragoza, Confederación Hidrográfica del Ebro).

Clemmens A.J. \& Dedrick A.R. (1994) Irrigation techniques and evaluations, in: K.K. Tanji \& B. Yaron (ed.) Adv. series in agricultural sciences (Berlin, Springer-Verlag).

Clemmens, A. J., Allen, R. G. \& Burt, C. M. (2008) Technical concepts related to conservation of irrigation and rainwater in agricultural systems, Water Resources Research, 44, pp. 1-16.

Dechmi, F., Playán, E., Faci, J.M., Tejero, M. \& Bercero, A. (2003) Analysis of an irrigation district in northeastern Spain: II: Irrigation evaluation, simulation and scheduling, Agric. Wat. Manage., 61, pp. 93-109.

Faci, J.M., Bensaci, A., Slatni, A. \& Playán, E. (2000) A case study for irrigation modernisation: I. Characterisation of the district and analysis of water delivery records, Agric. Wat. Manage., 42, pp. 313-334.

Forteza del Rey, V. (2002) El Plan Nacional de Regadíos, Agricultura, 842, pp. 554-556.

Hargreaves G.H. \& Samani Z.A. (1985) Reference crop evapotranspiration from temperature, Appl. Eng. Agric., 1(2), pp. 96-99. 
Herrero, J. \& Snyder, R. L. (1997) Aridity and irrigation in Aragon, Spain, Journal of Arid Environments 35(3), pp. 535-547.

IBRD (2009) Global Economic Prospects, Commodities at the crossroads (Washington DC, International Bank for Reconstruction and Development, The World Bank).

INE (1999) Censo agrario. Instituto Nacional de Estadística, Available at http://www.ine.es/inebmenu/mnu_agricultura.htm\#1 [Viewed: November 2007].

Isidoro, D., Quílez, D. \& Aragüés, R. (2004) Water balance and irrigation performance analysis: La Violada irrigation district (Spain) as a case study, Agric. Wat. Manage., 64(2), pp. 123-142.

Isidoro, D., Quílez, D. \& Aragüés, R. (2006a) Environmental impact of irrigation in La Violada District (Spain): I. Salt export patterns, Journal of Environmental Quality, 35(3), pp. 766-775.

Isidoro, D., Quílez, D. \& Aragüés, R. (2006b) Environmental impact of irrigation in La Violada District (Spain): II. Nitrogen fertilization and nitrate export patterns in drainage water, Journal of Environmental Quality, 35(3), pp. 776-785.

Isidoro, D. \& Aragüés, R. (2007) River water quality and irrigated agriculture in the Ebro basin: An overview, International Journal of Water Resources Development, 23(1), pp. 91-106.

Jensen, M. E. (2007) Beyond irrigation efficiency, Irrig. Sci., 25(3), pp. 233-245.

Keller A., Keller, J. \& Seckler, D. (1996) Integrated water resource systems: Theory and policy implications, Research Report 3 (Colombo, International Water Management Institute).

Krinner, W., Garcia, A. \& Estrada, F. (1994) Method for estimating efficiency in Spanish irrigation systems, J. Irrig. and Drain. Engrg., 120(5), pp. 979-987.

Lecina, S., Monserrat, J. \& Cots, L. (2000) El uso del agua en el regadío de Flumen (II). Zona noroccidental de la Acequia de Rufas (Huesca), Riegos y Drenajes XXI, 112, pp. 39-41. 
Lecina, S., Playán, E., Isidoro, D., Dechmi, F., Causapé, J. \& Faci, J.M. (2005) Irrigation evaluation and simulation at the irrigation district V of Bardenas (Spain), Agric. Wat. Manage., 73, pp. 223-245.

Lecina, S. \& Playán, E. (2006a) A model for the simulation of water flows in irrigation districts: II. Application, J. Irrig. and Drain. Engrg., 132(4), pp. 322-331.

Lecina, S. \& Playán, E. (2006b) A model for the simulation of water flows in irrigation districts: I. Description, J. Irrig. and Drain. Engrg., 132(4), pp. 310-321.

López-Moreno, J. I., Beniston, M. \& García-Ruiz, J. M. (2008) Environmental change and water management in the Pyrenees: Facts and future perspectives for Mediterranean mountains, Global and Planetary Change, 61(3-4), pp. 300-312.

Martínez-Cob, A. (2004) Revisión de las necesidades hídricas netas de los cultivos de la cuenca del Ebro (Zaragoza, Confederación Hidrográfica del Ebro). Unpublished.

Martínez-Cob, A., Playán, E., Zapata, N., Cavero, J., Medina, E. T. \& Puig, M. (2008) Contribution of evapotranspiration reduction during sprinkler irrigation to application efficiency, J. Irrig. and Drain. Engrg., 134, pp. 745-756.

Mateos, L. (2008) Identifying a new paradigm for assessing irrigation system performance, Irrig. Sci., 27(1), pp. 25-34.

MARM (2000) Libro blanco del agua en España (Madrid, Ministerio de Medio Ambiente, Medio Rural y Marino).

MARM (2002) Plan Nacional de Regadios, Available at http://www.mapa.es/ es/desarrollo/pags/pnr/principal.htm [Viewed: November 2007].

MARM (2004) Análisis de la economía de los sistemas de producción. Resultados técnicoeconómicos de explotaciones agrícolas de Aragón en 2003 (Madrid, Ministerio de Medio Ambiente, Medio Rural y Marino).

MARM (2005) Análisis de la economía de los sistemas de producción. Resultados técnicoeconómicos de explotaciones agrícolas de Aragón en 2004 (Madrid, Ministerio de Medio Ambiente, Medio Rural y Marino). 
MARM (2006) Plan de Choque de Modernización de Regadíos, Available at http://www.plandechoque-ahorrodeagua.es [Viewed: November 2007].

MARM (2007) Encuesta sobre superficies y rendimientos de cultivos, Informe sobre regadios en España (Madrid, Ministerio de Medio Ambiente, Medio Rural y Marino).

Molden, D.J., Sakthivadivel, R., Perry, J., Fraiture, C. \& Kloezen W.H. (1998) Indicators for comparing performance of irrigated agricultural systems, Research Report 20 (Colombo, International Water Management Institute).

Molden, D. \& Sakthivadivel, R. (1999) Water accounting to assess use and productivity of water, International Journal of Water Resources Development, 15(1/2), pp. 55-71.

Molden, D., Oweis, T., Steduto, P., Bindraban, P., Hanjra, M. A. \& Kijne, J. (2009) Improving agricultural water productivity: Between optimism and caution, Agric. Water Manage., In Press, Corrected Proof. doi:10.1016/j.agwat.2009.03.023

Nogués, J., Herrero, J., Rodríguez-Ochoa, R. \& Boixadera, J. (2000) Land evaluation in a salt-affected irrigated district using an index of productive potential, Environmental Management, 25(2), pp. 143-152.

OECD-FAO. (2009) Agricultural Outlook 2009-2018, Highlights (Paris, Organisation for Economic Co-operation and Development - Food and Agriculture Organization of the United Nations).

Ongley, E.D. (1996) Control of water pollution from agriculture, FAO Irrigation and Drainage Paper 55 (Rome, FAO).

Perry, C. J. (1999) The IWMI water resources paradigm - definitions and implications, Agric. Wat. Manage., 40(1), pp. 45-50.

Perry, C. (2007) Efficient irrigation; Inefficient communication; Flawed recommendations, Irrigation and Drainage, 56 (4), pp. 367-378.

Perry, C., Steduto, P., Allen, R. G. \& Burt, C. M. (2009) Increasing productivity in irrigated agriculture: Agronomic constraints and hydrological realities, Agric. Water Manage., 96(11), pp. 1517-1524. 
Playán, E., Slatni, A., Castillo, R. \& Faci, J.M. (2000) A case study for irrigation modernisation: II. Scenario Analysis, Agric. Wat. Manage., 42, pp. 335-354.

Playán, E., Salvador, R., Faci, J.M., Zapata, N., Martínez-Cob, A. \& Sánchez, I. (2005) Day and night wind drift and evaporation losses in sprinkler solid-sets and moving laterals, Agric. Wat. Manage., 76, pp. 139-159.

Playán, E. \& Mateos, L. (2006) Modernization and optimization of irrigation systems to increase water productivity, Agric. Wat. Manage., 80, pp. 100-116.

Playán E., Cavero J., Mantero I., Salvador R., Lecina S., Faci J.M., Andrés J., Salvador V., Cardeña G., Ramón S., Lacueva J.L., Tejero M., Ferri J. \& Martínez-Cob A. (2007) A database program for enhancing irrigation district management in the Ebro Valley (Spain), Agric. Wat. Manage., 87, pp. 187-199.

Seckler, D. (1996) The new era of water resources management: from "dry" to "wet" water savings, Research Report 1 (Colombo, International Water Management Institute).

Seckler, D., Molden, D. \& Sakthivadivel, R. (2003) The concept of efficiency in waterresources management and policy, in: W. Kijne, R. Barkers \& D. Molden (Ed.) Water productivity in Agriculture: limits and opportunities for improvement (Wallingford, CAB International).

Steduto, P., Hsiao, T. C. \& Fereres, E. (2007) On the conservative behavior of biomass water productivity, Irrig. Sci., 25(3), pp. 189-207.

Tedeschi, A., Beltran, A. \& Aragüés, R. (2001) Irrigation management and hydrosalinity balance in a semi-arid area of the middle Ebro river basin (Spain), Agric. Wat. Manage., 49(1), pp. 31-50.

Turral, H., Svendsen, M. \& Faures, J. M. (2009) Investing in irrigation: Reviewing the past and looking to the future, Agric. Wat. Manage., In Press, Corrected Proof. doi:10.1016/j.agwat.2009.07.012

Willardson, L.S., Allen, R.G. \& Frederiksen, H.D. (1994) Elimination of irrigation efficiencies, in: USCID (Ed.) 13th Tech. Conf. USCID (Denver, USCID). 
Zapata, N., Playán, E., Martínez-Cob, A., Sánchez, I., Faci, J. M. \& Lecina, S. (2007) From on-farm solid-set sprinkler irrigation design to collective irrigation network design in windy areas, Agric. Wat. Manage., 87, pp. 187-199.

Zapata, N., Playán, E., Skhiri, A. \& Burguete, J. (2009) Simulation of a collective solidset sprinkler irrigation controller for optimum water productivity, J. Irrig. Drain. and Engrg., 135(1), pp. 13-24. 


\section{List of tables}

Table 1. Volume, total dissolved solids (TDS), nitrate concentration $\left(\mathrm{NO}_{3}^{-}\right)$, salt and nitrate loads and nitrate losses (as \% of $N$ fertilization) in the irrigation return flows of several experimental irrigated areas in the central Ebro River Basin. The electrical conductivity of the irrigation water is low $\left(<0.4 d S m^{-1}\right.$ at $\left.25^{\circ} \mathrm{C}\right)$ in all areas. Adapted from Basso, 1994; Causapé et al., 2004a,b; Cavero et al., 2003; Isidoro, 2006a,b; Tedeschi et al., 2001. 
Table 1. Volume, total dissolved solids (TDS), nitrate concentration $\left(\mathrm{NO}_{3}^{-}\right)$, salt and nitrate loads and nitrate losses (as \% of $N$ fertilization) in the irrigation return flows of several irrigated areas in the central Ebro River Basin. The electrical conductivity of the irrigation water is low $\left(<0.4 \mathrm{dS} \mathrm{m}^{-1}\right.$ at $\left.25^{\circ} \mathrm{C}\right)$ in all areas. Adapted from Basso, 1994; Causapé et al., 2004a,b; Cavero et al., 2003; Isidoro, 2006a,b; Tedeschi et al., 2001.

\begin{tabular}{|c|c|c|c|c|c|c|c|c|}
\hline \multirow[b]{2}{*}{ Zone } & \multirow[b]{2}{*}{$\begin{array}{c}\text { Area } \\
\text { ha }\end{array}$} & \multirow[b]{2}{*}{$\begin{array}{l}\text { Soil salinity } \\
E C_{e} d^{-1} ~ m^{-1}\end{array}$} & \multicolumn{6}{|c|}{ Annual irrigation return flows } \\
\hline & & & $\begin{array}{c}\text { Volume } \\
\mathrm{mm}\end{array}$ & $\begin{array}{l}\text { TDS } \\
\text { mg l}^{-1}\end{array}$ & $\begin{array}{l}\mathrm{NO}_{3}^{-} \\
\mathrm{mg} \mathrm{l}^{-1}\end{array}$ & $\begin{array}{l}\text { Salt load } \\
\text { t ha }^{-1}\end{array}$ & $\begin{array}{l}\text { Nitrate load } \\
\text { kg NO}_{3}^{-} \mathrm{ha}^{-1}\end{array}$ & $\begin{array}{c}\mathrm{NO}_{3}{ }^{-} \text {losses } \\
\%\end{array}$ \\
\hline \multicolumn{9}{|c|}{ SURFACE IRRIG. } \\
\hline Bardenas A & 95 & $<2,0$ & 755 & 541 & 58 & 4 & 98 & 44 \\
\hline Bardenas B & 216 & $<2,0$ & 1,113 & 423 & 77 & 5 & 195 & 56 \\
\hline Bardenas C & 409 & $2,0-6,0$ & 635 & 2,170 & - & 14 & - & - \\
\hline Violada & 3,866 & 2,2 (gypsum) & 989 & 1,751 & 28 & 20 & 83 & 26 \\
\hline Average & & & 958 & 1,702 & 31 & 19 & 89 & 28 \\
\hline \multicolumn{9}{|c|}{ SPRINKLER IRRIG. } \\
\hline Monegros II A & 494 & $2,0-6,0$ & 48 & - & 125 & - & 14 & 10 \\
\hline Monegros II B & 470 & $2,0-6,0$ & 194 & 6,983 & 112 & 14 & 49 & 22 \\
\hline Average & & & 119 & 6,983 & 119 & 14 & 31 & 16 \\
\hline
\end{tabular}




\section{List of figures}

Figure 1. Location of Ebro River Basin in the Iberian Peninsula. The darker gray represents the irrigated areas in the basin.

Figure 2. Cropping patterns by irrigation systems in the Ebro River Basin (average from 1996 to 2002).

Figure 3. Gross land productivity by irrigation systems and crop groups in the Ebro River Basin (average of 2003 and 2004).

Figure 4. Beneficial evapotranspiration per unit area (50\% return probability) and gross land productivity by irrigation systems in the Ebro River Basin (cropping pattern referred to the average from 1996 to 2002; crop prices referred to the average of 2003 and 2004). 
Figure 1. Location of Ebro River Basin in the Iberian Peninsula. The darker gray represents the irrigated areas in the basin.

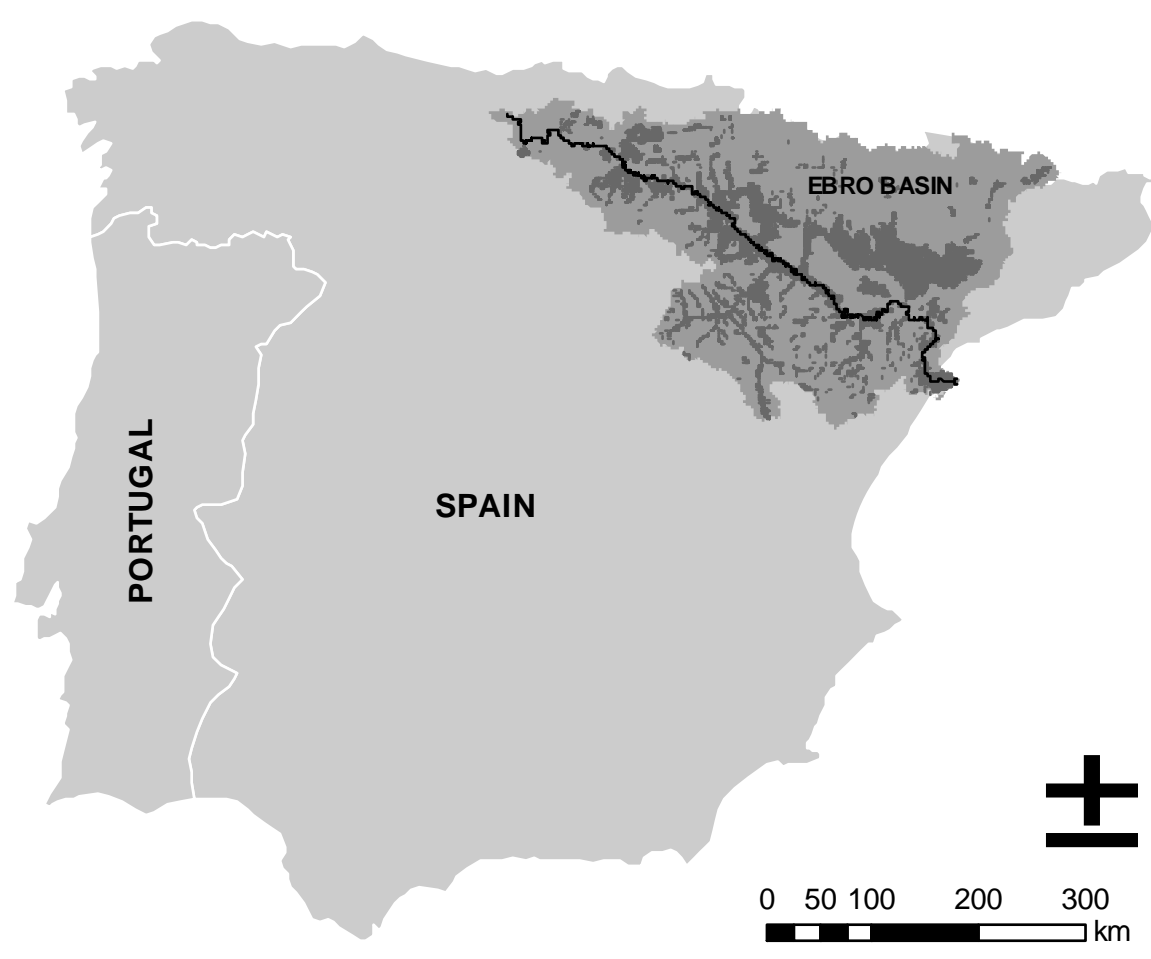


Figure 2. Cropping patterns by irrigation systems in the Ebro River Basin (average from 1996 to 2002).

A. Total

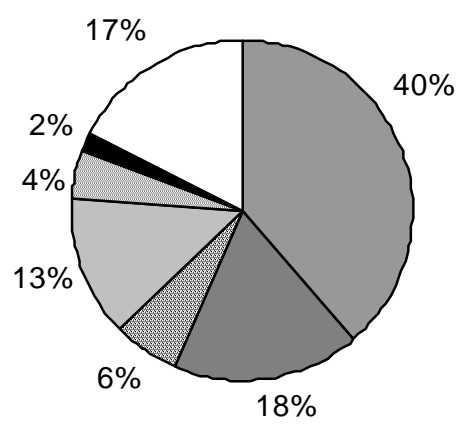

B. Surface irrigation

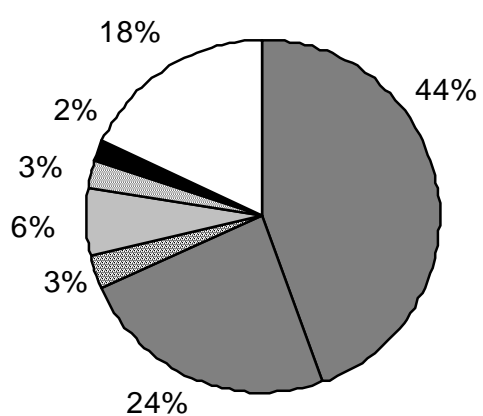

\section{Pressurized irrigation}

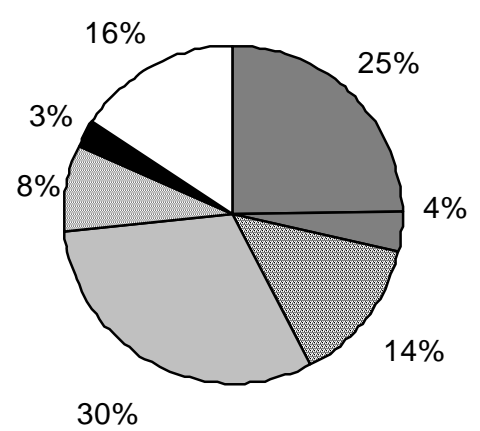

$\square$ Summer field crops $\square$ Winter field crops $\square$ Vegetables $\quad \square$ Fruits $\square$ Vineyard \& Olives $\quad \square$ Others $\square$ No crop 
Figure 3. Gross land productivity by irrigation systems and crop groups in the Ebro River Basin (average of 2003 and 2004).

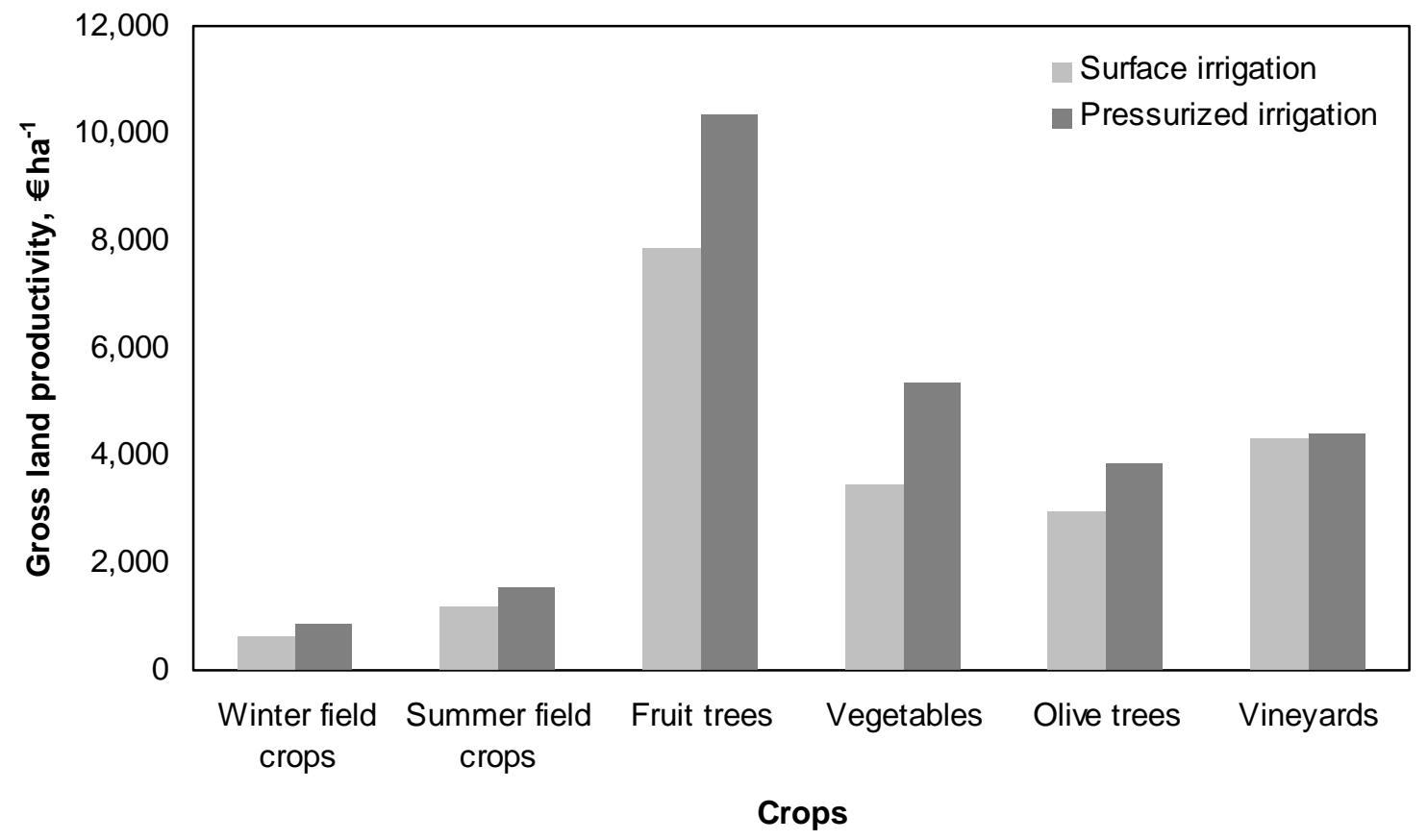


Figure 4. Beneficial evapotranspiration per unit area (50\% return probability) and gross land productivity by irrigation systems in the Ebro River Basin (cropping pattern referred to the average from 1996 to 2002; crop prices referred to the average of 2003 and 2004).

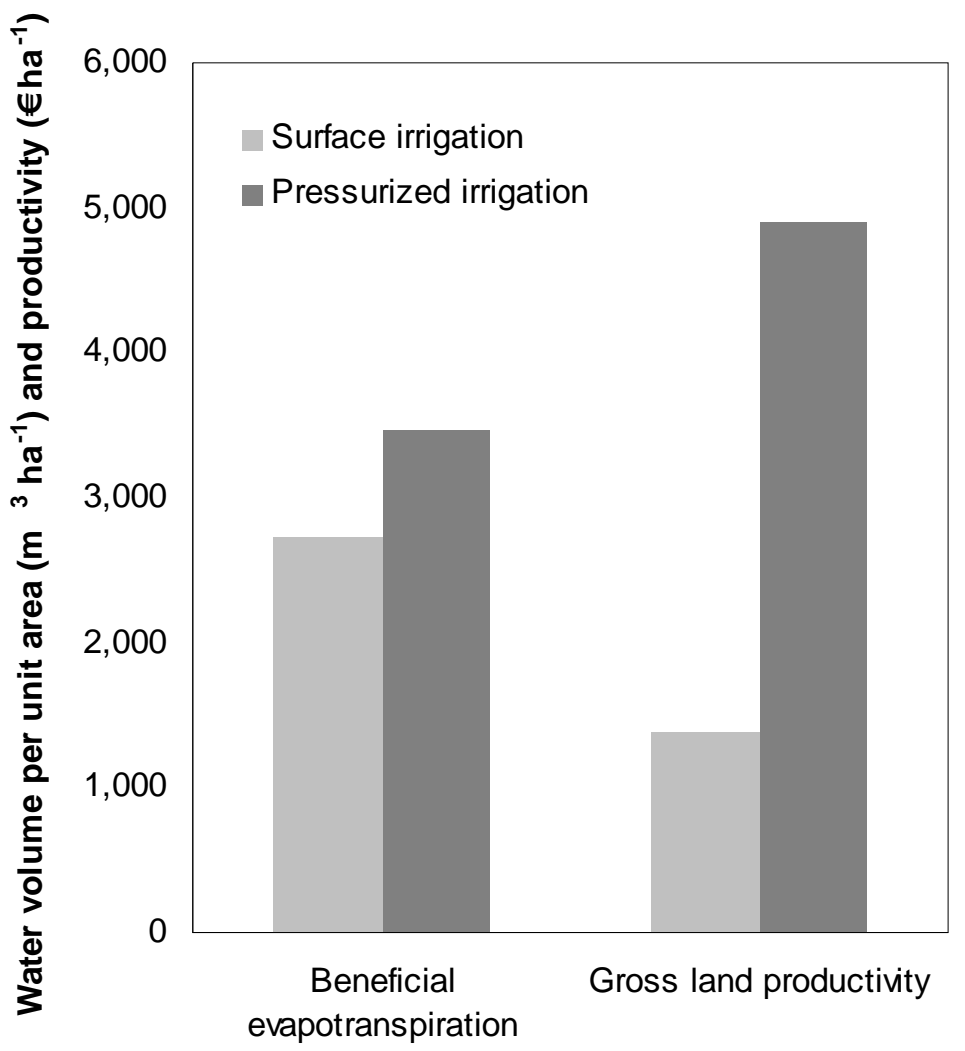

